\title{
Measurement of ATP Generation and Decay in Mycobacterium leprae in vitro
}

\author{
By YOUNG NAM LEE AND M. JOSEPH COLSTON* \\ Laboratory for Leprosy and Mycobacterial Research, National Institute for Medical Research, \\ Mill Hill, London NW7 1AA, UK
}

(Received 15 May 1985; revised 30 July 1985)

The intracellular ATP content of Mycobacterium leprae isolated from armadillo tissue was approximately $1.5 \times 10^{-16} \mathrm{~g}$ per bacillus. During in vitro incubation of bacilli at $4{ }^{\circ} \mathrm{C}, 33^{\circ} \mathrm{C}$ or $37^{\circ} \mathrm{C}$ there was an exponential decrease in ATP content, the rate depending on the medium and the temperature. $M$. leprae incorporated phosphate into ATP and into other nucleotide materials during in vitro incubation.

\section{INTRODUCTION}

Mycobacterium leprae, the human leprosy bacillus, has not been grown in vitro. However, the availability of large numbers of organisms from experimentally infected nine-banded armadillos has enabled studies on the metabolism and biochemistry of $M$. leprae to be initiated (for a review see Wheeler, $1984 a$ ). Such studies have revealed, for example, that $M$. leprae is capable of in vitro incorporation of purines and pyrimidines (Khanolkar \& Wheeler, 1983) and of catabolizing carbon sources such as glucose, glycerol and 6-phosphogluconate (Wheeler, 1983), and that it possesses key enzymes of the tricarboxylic acid cycle (Wheeler, 1984b).

One of the main objectives in studying the intermediary metabolism of $M$. leprae is to gain a better understanding of the biochemical relationship between the organisms and the host, and hence to arrive at a rational basis for devising culture media. However, the main problem with studying the in vitro cultivation of $M$. leprae is that multiplication or viability of the organism is difficult to demonstrate, requiring passage into mice and observation of the mice over many months. If methods for assessing the metabolic status of the organism could be devised, it should be possible to obtain much more rapid information on what happens to $M$. leprae during in vitro incubation.

In this study the possibility of measuring bacterial ATP as an indicator of metabolic status has been investigated. Using this approach successful cultivation of $\boldsymbol{M}$. lepraemurium has been achieved in the last few years, and attempts have also been made to measure the concentration of ATP in M. leprae (Dhople \& Hanks, 1981; Dhople \& Storrs, 1982). In the absence of successful cultivation, the measurement of bacterial ATP could provide a means of assessing bacterial viability. We have measured the intracellular ATP content of $M$. leprae isolated from armadillo tissues and have followed the changes in ATP content during in vitro incubation in a variety of culture conditions, and we have demonstrated that, in spite of its inability to multiply, $M$. leprae is capable of synthesizing ATP in vitro.

\section{METHODS}

Organisms and media. Mycobacterium leprae was purified from the spleen or liver of experimentally infected nine-banded armadillos according to the most recent IMMLEP procedure (World Health Organization, 1980).

\footnotetext{
Abbreviations: BT, buffered-Tween; HBSS, (modified) Hanks' balanced salts solution; NT, nutrient-Tween medium; TG, thioglycollate medium; PEI-cellulose, polyethyleneimine-cellulose.
} 
Briefly, this involves the release of bacteria from tissue by homogenizing in hypotonic-alkaline buffer $(0 \cdot 135 \mathrm{M}$ $\mathrm{NaCl} / 0 \cdot 2 \mathrm{M}$-Tris base/1 mm- $\mathrm{MgSO}_{4} / 1 \mathrm{~mm}$-benzamidine hydrochloride), differential centrifugation, DNAase treatment, separation of bacteria from tissue debris on a Percoll gradient $(30 \%, \mathrm{w} / \mathrm{v})$ and further purification using a two-phase system consisting of aqueous dextran and polyethylene glycol. Organisms were purified from fresh tissue or from tissue which had been frozen and stored at $-80^{\circ} \mathrm{C}$. In some experiments irradiated $M$. leprae cells were used; these were purified from tissues which had been treated with $2.5 \mathrm{mrad}{ }^{60} \mathrm{Co}$ prior to storage at $-80{ }^{\circ} \mathrm{C}$. Purified $M$. leprae cells were suspended in Hanks' balanced salts solution containing $0.05 \%$ Tween- 80 but without phenol red (HBSS) (K vach \& Veras, 1982), in nutrient-Tween medium (NT) (Mac Naughton \& Winder, 1977), or in thioglycollate medium (TG; Difco). Contamination of $M$. leprae suspensions with cultivable organisms was monitored by incubating samples in brain heart infusion broth, on blood agar and on Lowenstein-Jensen medium. In experiments where $M$. leprae was treated with $\mathrm{NaOH}$, suspensions were incubated in $0.5 \mathrm{M}-\mathrm{NaOH}$ for $1 \mathrm{~h}$ at room temperature, neutralized with $1 \mathrm{M}$-HEPES buffer and washed three times with buffered-Tween (BT; $0.1 \%$ Tween 80 in 1 mM-MES, pH 6.8) (Wheeler et al., 1982). Total counts of $M$. leprae were carried out according to published procedures (Hart \& Rees, 1960).

Mycobacterium smegmatis NCTC 10265 was grown aerobically in either NT or a glucose medium (MacNaughton \& Winder, 1977) modified by containing $0.136 \mathrm{~g}$ instead of $5 \mathrm{~g} \mathrm{KH}_{2} \mathrm{PO}_{4} 1^{-1}$ (low-phosphate/ glucose medium).

Extraction of ATP from mycobacteria. One volume of bacterial suspension, usually $20-30 \mu$, was mixed with two volumes of $100 \mathrm{~mm}$-Tris/2 mM-EDTA buffer, $\mathrm{pH} \mathrm{7.75}$, and the mixture placed in a boiling water bath for $5 \mathrm{~min}$.

ATP Assay. ATP in bacterial extracts was measured by the firefly luciferin-luciferase assay system (Chappelle \& Levin, 1968). Picozyme F (40 $\mu$ l; equivalent to $4 \times 10^{5}$ units of luciferin-luciferase, Packard Instrument Co.) was added to $10 \mu \mathrm{l}$ bacterial extract. After a $10 \mathrm{~s}$ delay, luminescent counts were recorded for $30 \mathrm{~s}$ at $24^{\circ} \mathrm{C}$ on a Packard Picolite model 6100 Luminometer. The concentration of ATP in the extracts was calculated by comparing luminescent counts obtained using a standard ATP solution (Picochec, Packard).

Treatment of $M$. leprae with apyrase. M. leprae was incubated with 1 unit of apyrase (EC 3.6.1.5, Sigma) in $50 \mathrm{~mm}$-MES buffer, pH 6.5 for $20 \mathrm{~min}$ at $37^{\circ} \mathrm{C}$. The organisms were then washed three times with BT.

Uptake of $\left[U-{ }^{14} \mathrm{C}\right] A T P$ by $M$. leprae. $M$. leprae cells were incubated in low-phosphate/glucose medium supplemented with $5 \mu \mathrm{Ci}$ [U-1 ${ }^{14} \mathrm{C}$ ]ATP (specific radioactivity $515 \mathrm{mCi} \mathrm{mmol}^{-1}, 19 \cdot 1 \mathrm{GBq} \mathrm{mmol}^{-1}$; Amersham) $\mathrm{ml}^{-1}$ for $24 \mathrm{~h}$ at $37^{\circ} \mathrm{C}$. Incorporation of $\left[{ }^{14} \mathrm{C}\right] \mathrm{ATP}$ into bacteria was terminated by adding cold trichloroacetic acid (TCA) to $5 \%(w / v)$ concentration. Bacteria were collected on glass microfibre filter discs (Whatman GF/C) and washed with an excess volume (approximately $50 \mathrm{ml}$ ) of cold $5 \%$ TCA. Radioactivity incorporated into the bacteria was measured on a Beckman LS7000 counter.

Incorporation of $\left[{ }^{32} P\right]$ phosphate into nucleotides of $M$. leprae. Freshly purified $M$. leprae $\left(2 \times 10^{9}\right.$ bacilli) were incubated in $5 \mathrm{ml}$ of low-phosphate/glucose medium supplemented with $5 \mu \mathrm{Ci}(185 \mathrm{kBq}){ }^{32} \mathrm{P}$ (as carrier-free orthophosphate) per $\mathrm{ml}$ medium for $24 \mathrm{~h}$ at $36^{\circ} \mathrm{C}$, with occasional shaking. The same number of heat-killed $M$. leprae cells (boiled for $15 \mathrm{~min}$ ) was used in a parallel experiment as a measure of non-specific incorporation of ${ }^{32} \mathrm{P}$ into the nucleotide fraction of $M$. leprae. It was confirmed that the $M$. leprae suspension was free of contamination with cultivable mycobacteria as well as other bacteria.

Extraction of ${ }^{32} P$-labelled nucleotides from in vitro-incubated $M$. leprae. Cells of $M$. leprae were collected on type GS Millipore filter discs (pore size $0.22 \mu \mathrm{m}$ ) and the discs allowed to stand for $20 \mathrm{~min}$, with occasional vortexing, in $2 \mathrm{ml}$ ice-chilled $1 \mathrm{M}$-formic acid saturated with 1-butanol (10\%, v/v, 1-butanol) (Olempska-Beer \& Freeze, 1984). Acid-soluble materials in the supernate were obtained by centrifugation for $5 \mathrm{~min}$ at 5000 r.p.m. $(3500 \mathrm{~g})$ (Bactifuge, Heraeus Christ), and then about $500 \mathrm{nmol}$ ATP (Sigma) was added to the supernate as an unlabelled carrier. Nucleotide materials were adsorbed onto acid-washed charcoal by addition of $30 \mathrm{mg}$ charcoal per ml of sample. After $10 \mathrm{~min}$ on ice, the charcoal was collected by centrifugation for $5 \mathrm{~min}$ at $3500 \mathrm{~g}$ at room temperature. Nucleotide materials were then eluted from the charcoal with $4 \mathrm{ml}$ of an ethanol/distilled and deionized $\mathrm{H}_{2} \mathrm{O} / \mathrm{NH}_{4} \mathrm{OH}$ solution $(50: 45: 5$, by vol.) (Sargent, 1977) through a Millipore HVLP Duromembrane filter disc (pore size $0.45 \mu \mathrm{m}$ ) (Olempska-Beer \& Freeze, 1984). The eluate was concentrated under vacuum at room temperature overnight and the residue resuspended in a minimum volume of distilled and deionized $\mathrm{H}_{2} \mathrm{O}$.

Two-dimensional chromatography of ${ }^{32} P$-labelled nucleotides extracted from $M$. leprae. Samples of the nucleotide extract were spotted onto polyethyleneimine (PEI)-cellulose $F$ thin-layer plastic sheets (Merck) and chromatographed first with $3.3 \mathrm{M}$-ammonium formate plus $4 \cdot 2 \%(\mathrm{w} / \mathrm{v})$ boric acid $(\mathrm{pH} 7 \cdot 0)$ and then with $0.75 \mathrm{M}-$ $\mathrm{KH}_{2} \mathrm{PO}_{4}(\mathrm{pH} 3.4)$. In between chromatography, the plates were soaked in methanol for 5 min, in distilled water for $15 \mathrm{~min}$ and then dried (Cashel et al., 1969). After chromatography, the plates were subjected to autoradiography.

\section{RESULTS}

\section{Intracellular ATP content of $M$. leprae}

The intracellular ATP content of $M$. leprae freshly purified from infected armadillo tissue ranged from 1.1 to $1.7 \times 10^{-16} \mathrm{~g}$ ATP per bacterium, with a mean of $1.45 \times 10^{-16} \mathrm{~g}$ 
Table 1. Effect of apyrase on quantification of ATP associated with $M$. leprae

The results of a single representative experiment are shown. A second experiment gave essentially identical results.

$\begin{array}{lccc}\text { Source of ATP } & \begin{array}{c}\text { Apyrase } \\ \text { treatment }\end{array} & \begin{array}{c}\text { Concn of ATP } \\ \text { measured }(\mathrm{M})\end{array} & \begin{array}{c}\text { Percentage } \\ \text { decrease due to } \\ \text { apyrase treatment }\end{array} \\ \text { Standard }\left(10^{-7} \mathrm{M}\right) & - & 10^{-7} & - \\ \text { Standard }\left(10^{-6} \mathrm{M}\right) & 0.5 \text { units } & 1.5 \times 10^{-10} & 99.99 \\ M \text {. leprae }\left(5 \times 10^{6} \text { cells }\right) & - & 5.3 \times 10^{-7 *} & - \\ M \text {. leprae }\left(5 \times 10^{6} \text { cells }\right) & 1.0 \text { units } & 5.7 \times 10^{-7 *} & 0 \\ & \text { * Mean of four determinations. }\end{array}$

(SE $0.09 \times 10^{-16}, n=6$ ). There was no difference in the values obtained for bacteria isolated from liver and those obtained for bacteria isolated from spleens. Freezing $\left(1{ }^{\circ} \mathrm{C} \mathrm{min}-1\right.$ to $-70{ }^{\circ} \mathrm{C}$ followed by immersion in liquid nitrogen) and thawing of $M$. leprae resulted in a $30-40 \%$ decrease in ATP content when the suspending medium was HBSS, and in a $20 \%$ decrease when is was TG. The ATP content of $M$. leprae purified from irradiated tissue $\left(1.57 \times 10^{-17} \mathrm{~g}\right.$ per bacterium; SE $0.31 \times 10^{-17}, n=3$ ) was only about $10 \%$ of the value for bacteria from fresh tissue. The ATP content of the cultivable mycobacterium $M$. smegmatis during the exponential growth phase $\left(2.17 \times 10^{-15} \mathrm{~g}\right.$ per viable bacterium; SE $\left.0.36 \times 10^{-16}, n=3\right)$ was an order of magnitude greater than that in freshly purified $M$. leprae, though it should be noted that this calculation was based on viable counts of $M$. smegmatis as opposed to total microscope counts for M. leprae.

The question then arose as to whether the ATP detected in $M$. leprae was genuine intracellular ATP or whether it could have been due to contamination with host tissue. Treatment of the purified bacteria with $\mathrm{NaOH}$, a procedure extensively used to eliminate host tissue contamination (Wheeler et al., 1982), did not produce a significant decrease in ATP levels. In two experiments ATP contents of $1.3 \times 10^{-16} \mathrm{~g}$ per bacterium and $1.7 \times 10^{-16} \mathrm{~g}$ per bacterium before $\mathrm{NaOH}$ treatment became $2.1 \times 10^{-16}$ and $2.7 \times 10^{-16} \mathrm{~g}$ per bacterium, respectively, after $\mathrm{NaOH}$ treatment. In addition, treatment of the bacteria with apyrase, under suitable conditions, prior to extraction of ATP, did not result in a significant change in ATP concentration (Table 1). This confirmed that the ATP was genuine $M$. leprae intracellular ATP rather than host-tissue-derived or bacterial-surface-bound extracellular ATP.

\section{Decay of intracellular ATP during in vitro storage or incubation of $M$. leprae}

The change in the intracellular ATP content of $M$. leprae during storage in different media at $4{ }^{\circ} \mathrm{C}$ is shown in Fig. 1. There was an exponential fall in ATP content over the two-week period of observation. ATP extracted from $M$. leprae and stored at $4{ }^{\circ} \mathrm{C}$ was stable, and there was no change in the ATP content of irradiated $M$. leprae during such storage. There was a marked difference in decay rates in different media, with the fastest decay occurring in BT (half-life $1.7 \mathrm{~d}$ ), and the slowest in TG medium (half-life $4.5 \mathrm{~d}$ ). NT and HBSS gave similar decay rates (half-life 2.7 and $2.5 \mathrm{~d}$, respectively).

The decay rate of $M$. leprae ATP during in vitro incubation was also dependent on the incubation temperature. At $37^{\circ} \mathrm{C}$ the half-life of ATP in M. leprae suspended in HBSS was $10 \mathrm{~h}$, compared to $21 \mathrm{~h}$ at $33^{\circ} \mathrm{C}$ and $2.5 \mathrm{~d}$ at $4^{\circ} \mathrm{C}$ (Fig. $2 a$ ). Similar results were obtained when the suspending medium was TG (Fig. $2 b$ ), although ATP decayed more rapidly in TG than in HBSS at $37^{\circ} \mathrm{C}$ and $33^{\circ} \mathrm{C}$.

\section{Uptake of exogenous ATP by $M$. leprae in vitro}

When viable $M$. leprae cells were incubated in vitro in low-phosphate/glucose medium containing $\left[{ }^{14} \mathrm{C}\right] \mathrm{ATP}$, the level of ${ }^{14} \mathrm{C}$ incorporation was lower than that seen with heat-killed controls (Table 2). The higher value seen in the controls was probably due to the clumping of bacilli during heat treatment, resulting in less effective washing. The addition of excess 


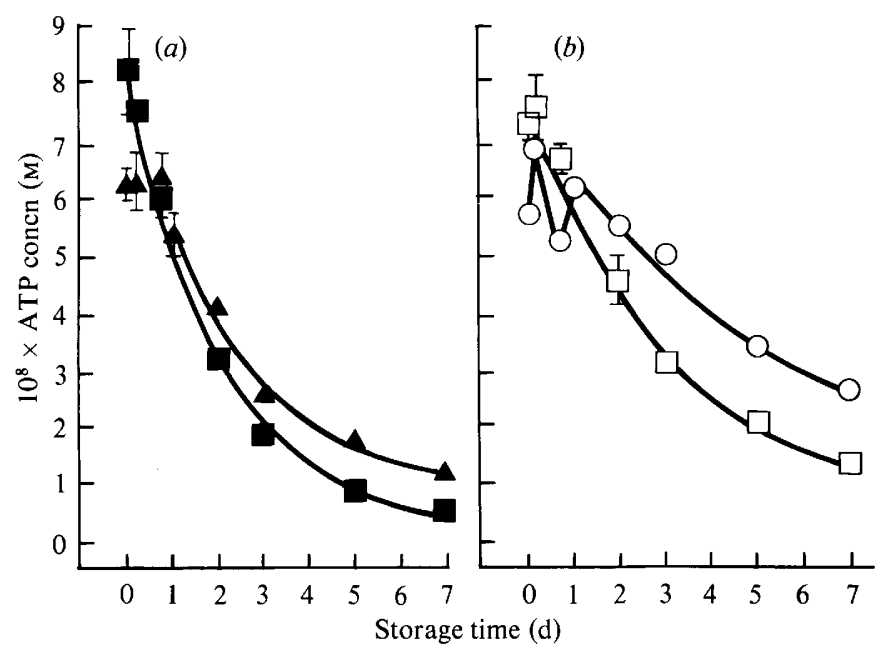

Fig. 1. Decay of intracellular ATP of $M$. leprae during storage of cells in different media at $4{ }^{\circ} \mathrm{C}$. ATP concentration was measured in $10 \mu \mathrm{l}$ samples extracted from $10^{6} \mathrm{M}$. leprae cells. Each point represents the mean of two determinations, with the range shown by the bars; where there are no bars, the two determinations were identical. $\boldsymbol{\square}, \mathrm{BT} ; \boldsymbol{\Delta}$, HBSS; $\square$, NT; O, TG.
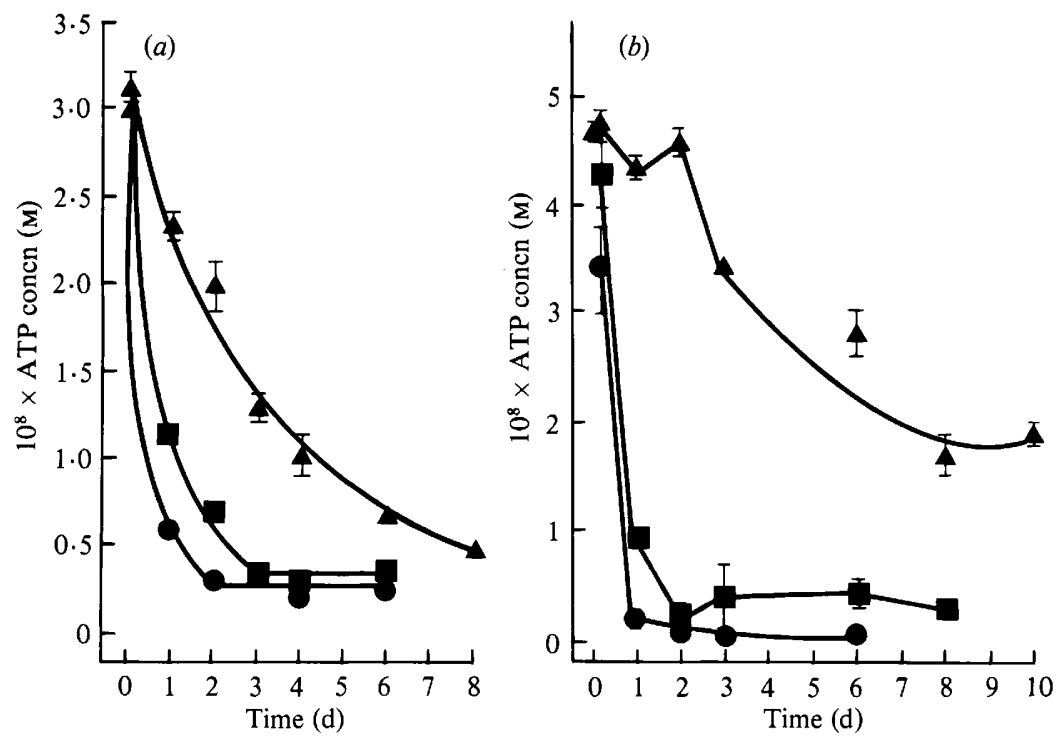

Fig. 2. Decay of intracellular ATP of $M$. leprae during incubation of cells at different temperatures $(a)$ in HBSS and $(b)$ in TG. ATP concentration was measured in $10 \mu 1$ samples extracted from $10^{6} M$. leprae cells. Each point represents the mean of two determinations, with the range shown by the bars; where there are no bars, the two determinations were identical. $0,37^{\circ} \mathrm{C} ; \square, 33^{\circ} \mathrm{C} ; \boldsymbol{\Delta}, 4{ }^{\circ} \mathrm{C}$.

unlabelled adenosine did not result in reduced levels of ${ }^{14} \mathrm{C}$ incorporation, suggesting that phosphatase activity was negligible. Using much higher numbers of $M$. leprae, phosphatase activity has been detected (P. R. Wheeler, personal communication). These results suggest that $M$. leprae is not able to take up ATP from its surrounding environment.

\section{Incorporation of phosphate into $M$. leprae ATP in vitro}

Both viable and heat-killed $M$. leprae were incubated for $24 \mathrm{~h}$ at $37^{\circ} \mathrm{C}$ in lowphosphate/glucose medium containing $\left[{ }^{32} \mathrm{P}\right]$ phosphate, and nucleotides were extracted and 

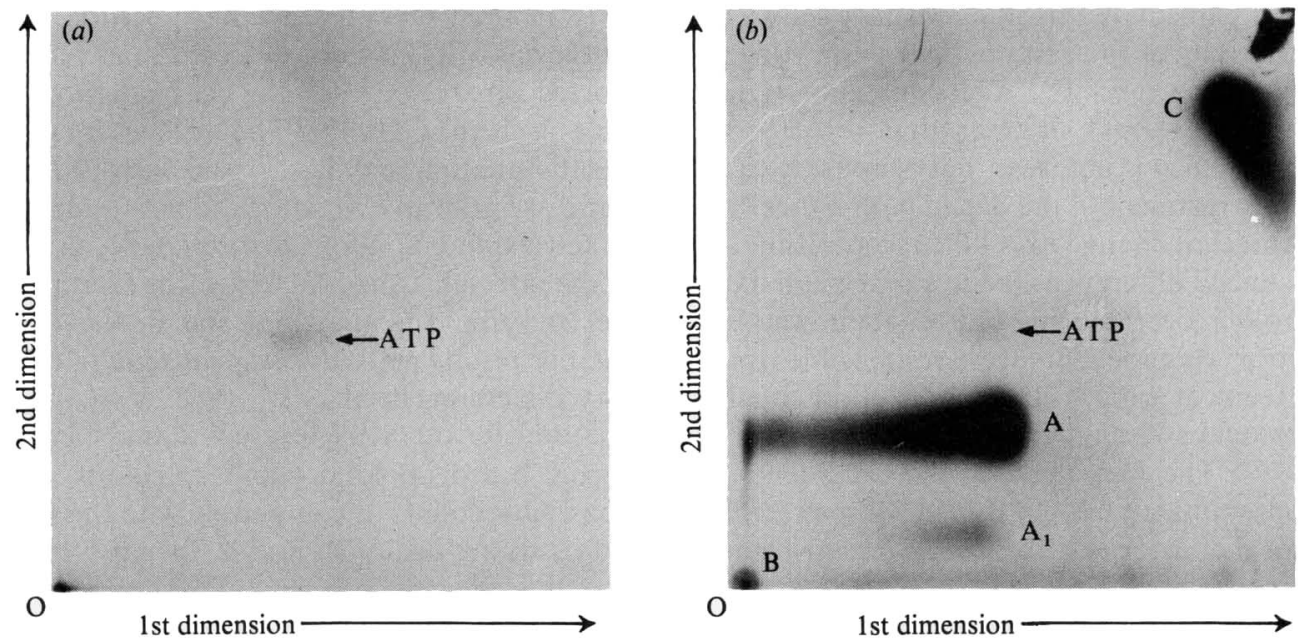

Fig. 3. Two-dimensional chromatography on PEI-cellulose plates of ${ }^{32} \mathrm{P}$-labelled nucleotides extracted from $M$. leprae after incubation with $\left[{ }^{32} \mathrm{P}\right]$ phosphate for $24 \mathrm{~h}$ at $37^{\circ} \mathrm{C}$. (a) Fluorescence of unlabelled carrier ATP added during the extraction procedure; $(b)$ autoradiogram of the $32 \mathrm{P}$-labelled nucleotides extracted from $M$. leprae.

\section{Table 2. Uptake of $\left[U^{14} C\right] A T P$ by $M$. leprae}

Cells were incubated for $24 \mathrm{~h}$ at $37^{\circ} \mathrm{C}$ in low-phosphate/glucose medium supplemented with $5 \mu \mathrm{Ci}$ $\left[{ }^{1+} \mathrm{C}\right]$ ATP $\mathrm{ml}^{-1}$. Where indicated, unlabelled adenosine $\left(25.7 \mathrm{mmol} \mathrm{m}^{-1}\right.$, equivalent to 10 times the concentration of $\left[{ }^{1+} \mathrm{C}\right] \mathrm{ATP}$ ) was also added. The results (means $\pm \mathrm{SE}, n=3$ ) of a single, representative experiment are shown. The experiment was repeated twice and essentially identical results were obtained.

\section{M. leprae $\left(2.5 \times 10^{8}\right.$ bacteria $)$}

Purified from armadillo, heated at $100^{\circ} \mathrm{C}$ for $15 \mathrm{~min}$ Purified from armadillo, untreated Purified from armadillo, untreated

\section{Unlabelled} adenosine

$\begin{array}{ll}- & 2575 \pm 70 \\ - & 1711 \pm 58 \\ + & 2188 \pm 66\end{array}$

Radioactivity in

TCA-insoluble material (c.p.m.)

$1711 \pm 58$

subjected to two-dimensional thin-layer chromatography. Autoradiography of the thin-layer plate after chromatography of extracts from viable cells (Fig. $3 b$ ) revealed a radiolabelled spot (arrowed) which exactly corresponded to the unlabelled ATP spot viewed under UV light (Fig. $3 a$ ). No such spot was observed when heat-killed $M$. leprae was used. A much more intense radiolabelled spot $(A)$ with a minor spot $\left(A_{1}\right)$ beneath it, was also observed in extracts from viable cells; these spots were apparent after a shorter $(14 \mathrm{~h})$ period of incubation, a time at which there was no detectable [ ${ }^{32}$ P]ATP. An additional spot (B) remained at the origin and a fourth spot (C) indicates the free [ $\left.{ }^{32} \mathrm{P}\right]$ phosphate front of the chromatogram. These results indicate that $M$. leprae is capable of taking up phosphate and incorporating it into ATP, and into other phosphate metabolic pathways.

\section{DISCUSSION}

There are two reasons why the measurement of intracellular ATP in $M$. leprae is important. First, it might provide a rapid means of measuring bacterial viability for studies involving cultivation, drug sensitivity measurement or drug screening. Secondly, studies of ATP generation and decay might be expected to give important information as to the factors affecting energy metabolism and hence lead to a better understanding of the nutritional requirements of 
the organism. In this study we have shown that ATP from $M$. leprae can be readily measured, the sensitivity of the assay system permitting significant levels of ATP to be detected in as few as $10^{5}-10^{6}$ bacteria. The ATP content of $M$. leprae reported here $\left(1.45 \times 10^{-16} \mathrm{~g}\right.$ per bacterium $)$ is approximately 100 times that reported by Dhople \& Hanks (1981). The reason for this discrepancy is not clear, but is unlikely to involve contamination with host-tissue-derived ATP since treatment of the bacilli with either $\mathrm{NaOH}$ or apyrase prior to extraction did not result in a significant change in ATP concentration. A more likely explanation for the discrepancy is that technical differences in the storage and handling of the infected armadillo tissue (for example a $30-40 \%$ decrease in ATP content was found after freezing and thawing) and in the ATP extraction procedure were responsible. In any event, our results with $M$. smegmatis are in close agreement with ATP contents of other cultivable mycobacteria (Prioli et al., 1985; V. Katoch, personal communication) as well as with those reported for other bacteria (Watanabe et al., 1979). The fact that the ATP content of $M$. leprae, based on total bacillary counts, was approximately $10 \%$ of that in $M$. smegmatis, based on viable counts, is compatible with the view that the majority of $M$. leprae organisms in infected tissue are dead (McRae \& Shepard, 1971; Sharp et al., 1985).

There was an exponential decrease in ATP concentration during in vitro incubation of $M$. leprae, although sometimes this followed a transient increase during the first 4 or $5 \mathrm{~h}$ incubation. The rate of decrease was dependent on the temperature of incubation and the nature of the suspending medium, with incubation at $37^{\circ} \mathrm{C}$ in nutrient-rich media (e.g. TG) producing the most rapid effect, suggesting that the decrease may be due to active utilization of ATP by $M$. leprae. Two important questions were posed by these results. First, what was the origin of the $M$. leprae ATP, i.e. does $M$. leprae generate its own ATP when growing in host tissue or is it capable of taking up and utilizing host ATP in the same way as host-energy-dependent organisms such as chlamydia (Hatch et al., 1982) and rickettsia (Winkler, 1976) ? Second, if $M$. leprae does generate its own ATP, does the mechanism by which it does so cease on in vitro incubation, or does ATP production continue but at a rate which does not match ATP utilization, hence resulting in a net decline in ATP concentration?

From the results shown in Table 2, it seems unlikely that $M$. leprae relies on its host for a supply of ATP, since it was unable to take up exogenous ATP when incubated in vitro. The fact that $M$. leprae is capable of generating its own ATP, and, in addition, that it continues to do so even during in vitro incubation is shown by the results illustrated in Fig. 3. Incorporation of ${ }^{32} \mathrm{P}$ into ATP was readily detectable after $24 \mathrm{~h}$ in vitro incubation. Whether this production is a transient phenomenon, or whether it continues for prolonged periods of in vitro incubation must be determined. Such studies on the energy metabolism of in vitro-incubated $M$. leprae should permit a more rational approach to the development of conditions favourable for cultivation. The results illustrated in Fig. 3 also indicate that ${ }^{32} \mathrm{P}$ is incorporated into other nucleotide materials. Attempts are being made to confirm the identity of these labelled metabolites with a view to gaining further insight into the ways in which the leprosy bacillus can generate and store energy.

Dr Young Nam Lee was supported by a grant from the Heiser Programme for Leprosy Research. We thank Dr Philip Draper and Dr P. R. Wheeler for their help and advice, and Mrs P. Christie for excellent secretarial assistance.

\section{REFERENCES}

Cashel, M., Lazzarini, R. A. \& Kalbacher, B. (1969). An improved method for thin-layer chromatography of nucleotide mixtures containing ${ }^{32} \mathrm{P}$ labelled orthophosphate. Journal of Chromatography 40, 103-109.

Chappelle, E. W. \& Levin, G. V. (1968). Use of the firefly bioluminescent reaction for rapid detection and counting of bacteria. Biochemical Medicine 2, 41-52.
Dhople, A. M. \& Hanks, J. H. (1981). Adenosine triphosphate content in Mycobacterium leprae. A brief communication. International Journal of Leprosy 49, 57-59.

Dhople, A. M. \& Storrs, E. E. (1982). Adenosine triphosphate content of Mycobacterium leprae. Effect of purification procedures. International Journal of Leprosy 50, 83-89.

HART, P. D'ARcy \& ReEs, R. J. W. (1960). Effect of 
macrocyclon in acute and chronic pulmonary tuberculous infection in mice as shown by visible and total bacterial counts. British Journal of Experimental Medicine 41, 414-420.

Hatch, T. P., Al-Hossainy, E. \& Silverman, J. A. (1982). Adenine nucleotide and lysine transport in Chlamydia psittaci. Journal of Bacteriology 150, 662670.

Khanolkar, S. R. \& Wheeler, P. R. (1983). Purine metabolism in Mycohacterium leprae grown in armadillo liver. FEMS Microbiology Letters 20, 272278.

Kvach, J. T. \& Veras, J. R. (1982). A fluorescent staining procedure for determining the viability of mycobacterial cells. International Journal of Leprosy. 50, 183-192.

MacNaughton, A. W. \& Winder, F. G. (1977). Increased DNA polymerase and ATP-dependent deoxyribonuclease activities following DNA damage in Mycobacterium smegmatis. Molecular and General Genetics 150, 301-308.

MCRAE, D. H. \& ShePARd, C. C. (1971). Relationship between the staining quality of Mycobacterium leprae and infectivity for mice. Infection and Immunity 3, 116-120.

Olempska-Beer, Z. \& Freeze, E. B. (1984). Optimal extraction conditions for high-performance liquid chromatographic determination of nucleotides in yeast. Analytical Biochemistry 140, 236-245.

Prioli, R. P., Tanna, A. \& Brown, I. N. (1985). Rapid methods for counting mycobacteria - comparison of methods for extraction of mycobacterial adenosine triphosphate (ATP) determined by firefly luciferase assay. Tubercle 66, 99-108.

SARGENT, M. (1977). Macromolecular synthesis in chromosome initiation mutants of Bacillus subtilis. Molecular and General Genetics 155, 329-338.
Sharp, A. K., Colston, M. J. \& Banerjee, D. K. (1985). Susceptibility of Mycobacterium leprae to the bactericidal action of mouse peritoneal macrophages and to hydrogen peroxide. Journal of Medical Microbiology 19, 77-84.

Watanabe, K., Takesue, S. \& Ishibashi, K. (1979). Adenosine triphosphate content in Lactobacillus casei and the blender-resistant phage cell complex forming ability of cells on infection with PL-1 phage. Journal of General Virology 42, 27-36.

WheEleR, P. R. (1983). Catabolic pathways for glucose, glycerol and 6-phosphogluconate in $\mathrm{Myco}$ bacterium leprae grown in armadillo tissues. Journal of General Microbiology 129, 1481-1495.

WhEELER, P. R. (1984a). Metabolism in Mycobacterium leprae: its relation to other research on $M$. leprae and to aspects of metabolism in other mycobacteria and intracellular parasites. International Journal of Leprosy 52, 208-230.

WhEELER, P. R. (1984b). Oxidation of carbon sources by the tricarboxylic acid cycle in Mycobacterium leprae grown in armadillo liver. Journal of General Microbiology 130, 381-389.

Wheeler, P. R., BharadwaJ, V. P. \& Gregory, D (1982). $N$-Acetyl- $\beta$-glucosaminidase, $\beta$-glucuronidase and acid phosphatase in Mycobacterium leprae. Journal of General Microbiology 128, 1063-1071.

WINKLER, H. H. (1976). Rickettsial permeability: an ADP-ATP transport system. Journal of Biological Chemistry 251, 389-396.

World Health Organization (1980). UNDP/World Bank/WHO Special Programme for Research and Training in Tropical Diseases. Report of the Fifth Meeting of the Scientific Working Group on the Immunology of Leprosy (IMMLEP) TDR/IMMLEPSWG Annex 4, 123(5)/80.3. Geneva, 24-26 June 1980. 